\title{
Book reviews in the age of social media
}

\author{
Norman A. Johnson*
}

\begin{abstract}
Despite the large quantity and wide variety of popular science books available in biology, most undergraduate biology majors seldom read full-length books outside of class. To ensure that the students in my Writing in Biology class are exposed to such books, I assign a book review essay and provide an annotated list of a few dozen books in genetics, evolution, and other areas of biology. The assignment also includes a section on the book author's style, in which students use material discussed earlier in the class. Informal presentations of the books provide opportunities for various discussions. The assignment (including the list of books) is included in an Additional file 1.
\end{abstract}

Keywords: Book review, Education, Popular science, Reading, Writing

Educators often bemoan the lack of reading by their students. They are especially concerned that students seldom read long-form works, such as popular science books. Although some of this concern may be perennial angst about the younger generations not doing what the educators perceived that they did at the same age, I suspect that in this age of distraction, college students read fewer books than they did in earlier decades.

Encouraging students to read more has many benefits. Time undergraduates spend reading for pleasure is correlated with grade point average in Gallik (1999). Although correlation does not necessarily imply causation, we should expect students who read more to do better in their coursework.

Shibley et al. (2008) discuss several ways where popular science books can promote active learning. Popular science books are more likely to engage students than the typical textbook. With each student taking on a book of their choosing, individual students are given more control over their learning. Sharing the information about the book during class presentations and other discussions (both inside and outside the classroom) allows students the opportunity to teach each other. In addition to the reasons given by Shibley et al. (2008), reading popular

*Correspondence: njohnson@ent.umass.edu

Department of Biology, University of Massachusetts-Amherst, Amherst, MA 01003, USA science books (along with guidance from the instructor) also gives students examples of how to write science for a variety of audiences and how to organize their thoughts. For other examples of how popular science books have been integrated into science curricula, see Lam (2000) and Prud'homme-Ge'ne'reux (2016).

At the University of Massachusetts at Amherst, I regularly teach sections of "Writing in Biology". Among their major assignments is a book review essay with each student working alone on their essay. This class, which is capped at 25 students, consists mainly of juniors and seniors. I provide students with a list of recent books (see Additional file 1) from which they can choose a book. I also allow students to pick a recent book on a topic in biology that not on the list subject to my approval.

The books on this list come from my own reading and are ones that I recommend to students. Thus, these books are but a subset of good popular books that are available. Almost all of the books on my list are less than 10 years old and all are less than 15 years old. I regularly update the list, adding newer books and removing the older ones. I also generally do not allow students to pick older books that are not on the list. I focus on recent books for several reasons. First, I want to demonstrate that science writing is an active field and that a considerable number of popular books in biology continue to come out. The more recent books also expose students to the new technology and original author(s) and the source, provide a link to the Creative Commons licence, and indicate if changes were made. The images or other third party material in this article are included in the article's Creative Commons licence, unless indicated otherwise in a credit line to the material. If material is not included in the article's Creative Commons licence and your intended use is not permitted by statutory regulation or exceeds the permitted use, you will need to obtain permission directly from the copyright holder. To view a copy of this licence, visit http://creativecommons.org/licenses/by/4.0/. The Creative Commons Public Domain Dedication waiver (http://creativeco $\mathrm{mmons}$.org/publicdomain/zero/1.0/) applies to the data made available in this article, unless otherwise stated in a credit line to the data. 
ideas-for instance CRISPR, ancient DNA, and the microbiome-that has come out in recent years. Second, the authors of more recent books also are more diverse (in background, gender, ethnicity, and other characteristics) than the authors of older books, especially the "classics". Finally, I want students to work with books that they are unlikely to have encountered before. I do not want students using a book that they read in high school for this assignment.

During the first half of each term, we discuss Stephen Pinker's Sense of Style (Pinker 2014), which is a guide for clearer academic writing. I also assign exercises based on material in Pinker's book. To reinforce what we have learned from Pinker's book, the book review assignment includes a section on the book author's style. Here, I have the students explicitly mention material in Pinker's book while commenting on the book author's style. This aspect of the assignment could be modified if a different style guide is used in the class.

I have the students each informally discuss their books in class when they turn in their assignments. Here, their classmates can ask them questions. At the end of these informal presentations, I have the students write out which of the books from their classmates' presentations they found most intriguing and why. I've found that these discussions often get students more interested in reading more books.

The perennial favorite of my students is Why Dogs Love Us by Berns (2013). Motivated by wanting to know the emotional responses of his pet dogs, the neurobiologist Berns described how he was able to assess neural activity in dogs as they experiencing as they interact with their owners. In addition to allowing Berns to present his motivations for the project, the first-person narrative provides Berns with the space to highlight the challenges and blind alleys involved in the research. Readers see how Berns got dogs to sit still-without drugs-in MRI machines for long enough time to get useful images. This narrative approach is a departure from most of what the typical undergraduate student reads about research in biology; textbooks and primary literature articles almost always focus on the results and methodology, rather than the reasoning behind newly devised methodology and the false starts taken. Classroom discussion about Berns (2013) allows for a discussion about how research is often done in practice.

I usually impose a limit of three different students reading the same book in order to avoid repetition and the temptation to work together on the same book. Each semester, I often have two or three students reading Berns (2013), which allows for the articulation of different perspectives of the same book. A mixture of a few students reading the same book while most read different ones appears ideal for fostering interesting and diverse class discussions.

In recent years, several of my students have read by How to Tame a Fox (and Build a Dog) by Dugatkin and Trut (2017) about an experiment to use artificial selection to breed for tamer foxes. This experiment, which started in what was then the Soviet Union in the late 1950s, has been extraordinarily successful both in producing foxes that are about as tame as dogs and in revealing insights into the process of domestication. One of the authors (Trut) has been leading the experiment for several decades. Like Berns (2013), this book is useful for showing students the process behind research in biology. Because the experiment started when the ghosts of Stalin and Lysenko still had considerable influence over science in the Soviet Union, this book is also useful in sparking discussion about Lysenkoism and how science can be perverted. I suspect that part of the popularity of both Berns (2013) and Dugatkin and Trut (2017) is that humans are fascinated by dogs, perhaps even more than we are about ourselves.

One discussion topic that I would like to pursue in future uses of this assignment include the consequences of evolution of evolutionary biology in understanding human diversity. Reich (2019) provides an excellent account of the uses of ancient DNA to better understand our history. Ancient DNA, a field that has burgeoned over the past decade, not only shows that we have exchanged genes with Neanderthals and Denisovans, but that human populations have always been exchanging genes with other populations: there is no such thing as a pure population.

In the latest iteration of my list prepared for teaching this class in Fall 2021 (and subsequent semesters), I added two recent books about the history of how science has been abused to justify racism and other abhorrent practices over the years: Saini (2019) and Okrent (2019). Okrent (2019) focuses on how many learned men used the then-new sciences of genetics and evolution to justify anti-immigration laws and forced sterilization during the late 19th and early 20th century. Saini (2019) takes a wider berth going from the development of race as a concept during the 16th and 17th century to continued abuses of science to justify racism in the genomic era. Student presentations of either one of these books would be useful jumping-off points to discuss the potential abuses of science to justify abhorrent practices as well as discussion for the need for more diversity and inclusion in biology.

In addition to discussing the content of the books during student presentations, we also use this time to discuss the style of these books using Pinker (2014) as a guide. One major theme in Pinker is that academic writing is 
often difficult to understand because the author knows the subject very well but forgets that some concepts and information are new to the reader. This pitfallwhat Pinker calls the curse of knowledge-is challenging across non-fiction writing in general but authors of popular science books usually succeed in not falling into this trap than most other non-fiction books. Exploring how these authors avoid the curse of knowledge, often through thoughtful metaphors, helps the students to write more clearly.

In my experience, most students have more difficulty writing coherent paragraphs than coherent sentences and still more difficulty in writing longer pieces. Pinker (2014) discusses the construction of longer works and how to maintain cohesion in them in detail. Although students work through exercises to practice this skill in class, experiencing how the authors of popular science books organize their works and build arguments and narratives often gives students insight that they can use in their own work, including a subsequent mini-review paper in the class.

Beyond each student learning something from the book that they read and from the class discussions, I hope that this book review assignment inspires my students to read more long-form, non-fiction books in biology after finishing the class and after they graduate. The long, annotated list of books associated with the assignment provides an excellent guide for further reading and should assist their life-long learning.

\section{Supplementary Information}

The online version contains supplementary material available at https://doi. org/10.1186/s12052-021-00154-y.

Additional file 1. Book review instructions and list of books.

\section{Acknowledgements}

None.

\section{Authors' contributions}

$\mathrm{NAJ}$ is the sole author and wrote the manuscript. The author read and approved the final manuscript.
Funding

No funding organizations were involved.

Availability of data and materials

This manuscript does not involve any data sets.

\section{Declarations}

Ethics approval and consent to participate N/A.

\section{Consent for publication}

The manuscript does not involve human participants. The manuscript does not involve animal subjects.

\section{Competing interests}

There are no competing interests.

Received: 25 August 2021 Accepted: 15 September 2021

Published online: 01 October 2021

\section{References}

Berns G. How dogs love us: a neuroscientist and his adopted dog decode the canine brain. Berrien Springs: Lake Union Publishing; 2013.

Dugatkin LA, Trut LA. How to tame a fox (and build a dog): visionary scientists and a Siberian tale of jump-started evolution. Chicago: University of Chicago Press; 2017.

Gallik JD. Do they read for pleasure? Recreational reading habits of college students. J Adolesc Adult Lit 1999:42:480-8.

Lam L. Integrating popular science books into college science teaching. Am Phys Soc Bull. 2000;45:117-24.

Okrent D. 2019. The guarded gate: bigotry, eugenics and the law that kept two generations of Jews, Italians, and other European immigrants out of America. Scribner.

Pinker S. The sense of style the thinking Person's guide to writing in the 21th century. London: Penguin Books; 2014.

Prud'homme-Ge'ne'reux A. Deconstructing a popular science book: fresh take on the book report. Am Biol Teach. 2016;78:248-53.

Reich D. Who are we and how we got here: ancient DNA and the new science of the human past. Oxford: Oxford University Press; 2019.

Saini A. Superior: the return of race science. Boston: Beacon Press; 2019.

Shibley I, Dunbar ME, Mysliwiec TH, Dunbar DA. Using science popularizations to promote learner-centered teaching: alternatives to the traditional textbook. J Coll Sci. 2008;38:54-9.

\section{Publisher's Note}

Springer Nature remains neutral with regard to jurisdictional claims in published maps and institutional affiliations.

\footnotetext{
Ready to submit your research? Choose BMC and benefit from:

- fast, convenient online submission

- thorough peer review by experienced researchers in your field

- rapid publication on acceptance

- support for research data, including large and complex data types

- gold Open Access which fosters wider collaboration and increased citations

- maximum visibility for your research: over $100 \mathrm{M}$ website views per year

At BMC, research is always in progress.

Learn more biomedcentral.com/submissions
} 